\title{
"THE LEGEND OF NAKHODA RAGAM" IN THE MALAY WORLD AND ITS LINK TO PENANG'S EARLY HISTORY
}

\section{("Legenda Nakhoda Ragam" di Alam Melayu dan Hubungannya dengan Sejarah Awal Pulau Pinang)}

\author{
Jelani Harun \\ jelani@usm.my \\ School of Humanities, \\ Universiti Sains Malaysia.
}

Published online: 1 December 2020

To Cite: Jelani Harun. (2020). "The Legend of Nakhoda Ragam" in the Malay World and Its Link to Penang's Early History. Malay Literature, 33(2), 149-168.

\begin{abstract}
The Malay World has produced many legends about extraordinary people such as rulers, nobles, warriors and the like. Patih Gajah Mada and Hang Tuah are examples of such legendary figures who possess a variety of extraordinary abilities and who are proudly regarded as idols of the community that produced them. Nevertheless, there are many other legendary figures who are not yet well known within the community but who have played no less than an important part in the history of the nation. Legends do not tell the life stories of ordinary persons; they showcase very special events associated with particular figures, which are then told and retold many times again. This article will discuss "Legenda Nakhoda Ragam" [The Legend of Nakhoda Ragam], which is well known in Brunei Darussalam, and his extraordinary adventures as a traveller in the Malay World, including his link to the founding of Pulau Pinang (Penang). Based on notes by Vaughan (1857), Nakhoda Ragam was a trader who often sailed between Lingga and Kedah. There was only one island between these two places that was attractive for him to anchor at, which he named "Pulo Ka Satu" (later Pulau Pinang or Penang). Nakhoda Ragam was also said to have founded several
\end{abstract}


other places here, among them "Pulo Kindi", "Bayan Lepas", "Gerattah Sangkol", "Pulo Bittong" and "Puchut Muka", which all still exist today. This article presents evidence regarding the presence of this figure and his connection to the early history of Penang.

Keywords: Nakhoda Ragam, legends, Brunei Darussalam, Penang

\begin{abstract}
Abstrak
Masyarakat Alam Melayu banyak melahirkan legenda yang telah memainkan peranan yang luar biasa selaku pemerintah, pembesar, pahlawan dan sebagainya. Nama seperti Patih Gajah Mada dan Hang Tuah merupakan sebahagian daripada legenda yang memiliki berbagaibagai kelebihan dan kehebatan serta menjadi tokoh kebanggaan masyarakat yang melahirkannya. Walau bagaimanapun, masih banyak legenda yang belum diketengahkan kepada khalayak masyarakat tetapi telah memainkan peranan yang tidak kurang hebatnya kepada sejarah sesebuah bangsa itu. Legenda bukan mengisahkan sejarah hidup seseorang tokoh yang biasa tetapi menampilkan peristiwa-peristiwa yang sangat istimewa yang berhubungan dengan tokoh tersebut sehingga menjadi sebutan masyarakat zaman-berzaman. Makalah akan membicarakan "Legenda Nakhoda Ragam" yang terkenal di Brunei Darussalam dan kisah kehebatan Nakhoda Ragam selaku seorang pengembara di Alam Melayu, termasuk hubungannya dengan sejarah awal pembukaan Pulau Pinang. Berdasarkan catatan Vaughan (1857), Nakhoda Ragam ialah seorang pedagang yang sering belayar di antara Lingga dan Kedah. Antara kedua-dua tempat itu, hanya ada sebuah sahaja pulau yang kelihatan sangat ketara untuk Nakhoda Ragam singgah, lalu dinamakannya sebagai "Pulo Ka Satu" (Pulau Pinang). Nakhoda Ragam juga dikatakan telah mengasaskan nama bagi beberapa tempat lain di sekitar pulau tersebut, antaranya termasuklah "Pulo Kindi", "Bayan Lepas", "Gerattah Sangkol", "Pulo Bittong" dan "Puchut Muka". Semua tempat ini masih wujud sehingga hari ini. Artikel ini mengemukakan bukti-bukti yang menunjukkan keberadaan tokoh ini dan kaitannya dengan sejarah awal Pulau Pinang.
\end{abstract}

Kata kunci: Nakhoda Ragam, legenda, Brunei Darussalam, Pulau Pinang 


\section{INTRODUCTION}

The deeds of a great historical figure are often embedded in the collective memory of his people for all time so he may be admired generation after generation, ultimately becoming a legend who is shared across different civilizations. Figures such as Sultan Mansur Shah, Badang, Tun Perak, Hang Tuah and Hang Jebat have filled the beautifully-wrought pages of the Sulalatus Salatin with their greatness and indeed have become legends in the history of Malay civilization. They are some of the figures who exemplify the best features of the Malays - wisdom, strength, justice, loyalty and couragewhich must continue to be the stalwart features of the Malay way of life even until the present day. These figures are legends at the local, regional and international stages. Even though studies of legends are nothing new, new source material about a legendary figure that requires further study and attention do occur from time to time. Legends are an important corpus in literary studies and can function to elaborate on human history. This article elaborates on "The Legend of Nakhoda Ragam", which is about the founder of the earliest Malay settlement on the island of Penang and is widely known in the Malay world.

\section{PENANG'S EARLY HISTORY}

Based on existing records, the name of the island was noted in the maps of Zheng He (Admiral Cheng Ho), who sailed to the Malay World around the $15^{\text {th }}$ century. Here, Penang is recorded as "Bin Lang Yu" (Kong Yuanzhi, 2000) or "Pin lang hsu" (Douglas, 1980, p. 477). ${ }^{1}$ To date, the sketches of these maps are probably the earliest extant documents recording the name of the island. Apart from Penang, other place names indicated in these maps are those of Langkawi and Kuala Kedah.

From among the European travellers, it is James Lancaster, an English captain who came to the Malay World in 1592, who recorded the "Ilands of Pulo Pinaom" or "Ilands of Pulo Pinaon" (Markham, 1877, pp. 10-27; Foster, 1940, p. 23). James Lancaster landed on "Pulo Pinaom" at least twice to rest and to treat sick crewmembers. Similarly, notes by Peter Floris, who came to the Malay World between 1611 and 1615, record an island named "Pulo Panying" (Moreland, 1934, p. 31).

In 1934, JMBRAS republished the notes of a European traveller named Navarette who had arrived in Melaka (also known as Malacca) in 1669. 


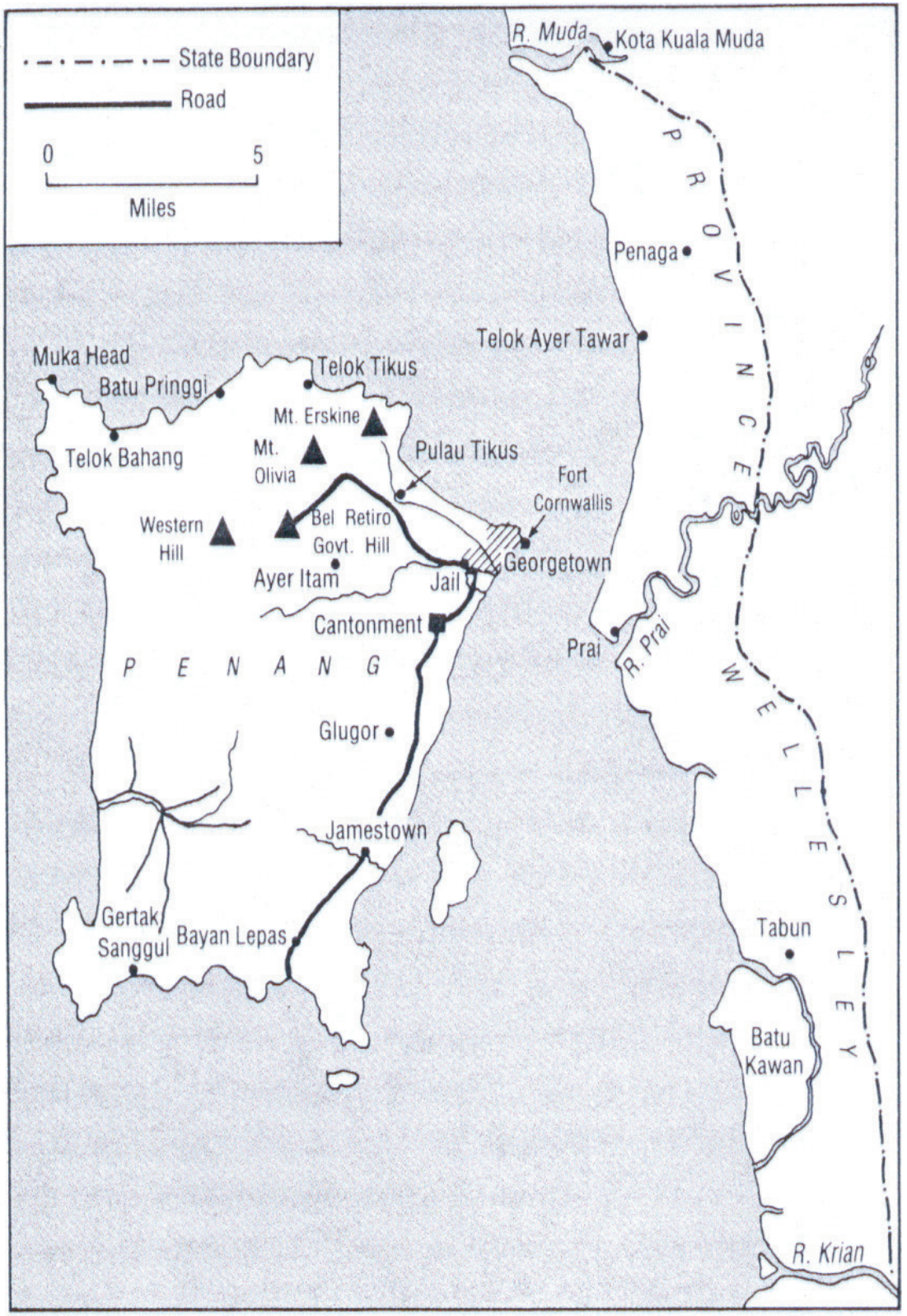

8. Penang and Province Wellesley in 1867.

Figure 1 Penang in 1867.

(Source: Hoyt, 2001, p. 23) 
Navarette's original notes in Spanish were translated as "An Account of the Empire of China". While on his travels, he had, among other places, stopped by an island named "Pulo Pinang" and rested on its beaches:

Thus we came to an island uninhabited, called Pulo Pinang, well wooded, there we took in water leisurely.

(Navarette, 1934, p. 93)

Based on the above, the island was already called "Pulau Pinang" long before the arrival of Francis Light on the island in 1786. In fact, further scrutiny of old maps sketched by European travellers in the $16^{\text {th }}$ and early $17^{\text {th }}$ centuries clearly indicate and name the island of Penang. For example, on a map of the Malay Peninsula by Langenes in 1595, the name "Pulo Pinaom" can clearly be seen (Suarez, 1999, p. 189). Similarly, a map drawn by Hondius in 1606 also indicates a "Pulo Pinaom" (Suarez, 1999, p. 196). ${ }^{2}$ In other words, the name of the island already existed around 200 years before the arrival of Francis Light on its shores.

The appearance of the name "Pulau Pinang" in the notes of Chinese and European travellers now makes these important documents about the early history of Penang become valuable. These notes are documentary evidence of Penang that cannot be erased from the knowledge of the global community. Nevertheless, the Malays have their own version concerning the etymology of the name "Pulau Pinang", in which it is linked to Nakhoda Ragam (Jelani, 2014). In this version of the orally-transmitted tale, Nakhoda Ragam is said to be the first person to name the island "Pulo Ka Satu" after discovering it; it later comes to be known as "Pulau Pinang". This calls for a re-examination of the figure Nakhoda Ragam, whose legend may well be based on historical fact, especially when linked to Sultan Bolkiah (1485-1524), who is known as "Nakhoda Ragam" in the history of the kingdom of Brunei Darussalam (Jelani, 2014).

\section{"Legenda Nakhoda Ragam"}

The existence of "Legenda Nakhoda Ragam" [The Legend of Nakhoda Ragam] is closely connected to Jonas Daniel Vaughan (1825-1891), a colonial officer who served in Singapore, Perak and Penang between 1845 and 1891. In 1851, he was made the Superintendent of Police of Penang 
LEGENDS \&C.

Trв Malays have a very pleasant way of whiling away an idle hour by relating stories to each other. Scarcely a locality exists but which has its Legend. Their names for things and places are invariably apt and illustrative, and their traditions need but a graphic pen to render them interesting to Europeans. A few extracts from their legendary lore will serve to show the truth of the above remarks.

The ancient name of Pulo Pinang was Pulo $\mathrm{Ka}$ Satu and thus do they account for its derivation.

A famous sea rover in days of yore named Ragam used to trade between Linga and Kidda and the adjacent rivers. Falling in with no higher or larger isolated island on the way than Pinang he named it Pulo Ka Satu or single island. The latter name' was retained till the betelnut palm was cultivated.on the island, after the arrival of the British, the name was when changed to Pulo Pinang. After Ragam's days and some time before the island became famous as Pulo Pinang, the natives of the opposite coast knew. it as Tanjong Panagar from trees of that name which grew on the spot where Fort Cornwallis is built. The inhabitants of Province Wellesley speak of Pulo Pinang to this day as Tanjong Panagar or its abbreviation Tanjong. The name may be seen in all the grants of land issued by government as late as 1800 .

To Ragam is imputed the names of all the bays, rivers and points of Pulo Pinang.

On one occasion when off the south western end of island, his kindi or waterpot fell into the sea, and it was immediately transformed by the genii of the place into an island which still bears the name of Pulo Kindi.

On leaving Pulo Kindi he pulled into a Bay which lies opposite the island, and at the mouth of the river which flows into the Bay he released a tame bird called Bayan, and thenceforth the river has been called Bayan Lepas (or the free Bayan).

At another time, when off the point forming one side of the above bay, he approached the shore for the purpose of landing. The sea was however too rough and in pulling from the shore his boat was nearly swamped; she rolled and pitched heavily,

Figure 2 "Legenda Nakhoda Ragam".

(Source: Vaughan, 1857) 
and was responsible to safeguard security and English interests in Penang. As part of his official duties in the colonial service, Vaughan had a personal interest in the daily lives of the multicultural population of Penang at the time. While in Penang, he made numerous notes about the local populace in terms of their history, culture, language and the like. One of his writings, titled "Notes on the Malays of Pinang and Province Wellesley", which was published in The Journal of the Indian Archipelago and Eastern Asia (1857), is now one of the most important documents about the early history of Penang.

In his writings, Vaughan recorded the interesting "Narrative of Haji Mohamed Salleh" (Vaughan, 1857, pp. 173-175). This narrative is said to have come from Haji Mohamed Salleh, one of the early pioneers of Penang, when Francis Light settled in the island in 1786. The story was passed on to the descendants of Haji Mohamed Salleh and narrated by one of them to Vaughan. The narrative is brief but contains a lot of information about the early history of Penang. The Haji Mohamed Salleh referred to here is different from another Haji Mohammad Salleh who was known as Nakhoda Intan, because the one mentioned here originated from Brunei Darussalam. For this reason, this Haji Mohamed Salleh was also known as Haji Brunei.

According to the story, Haji Mohamed Salleh was returning to Brunei after spending some time in Arabia. On the way, he stopped in Kedah and then Tanjong Penagar where he met Francis Light, who had just arrived on the island. According to Haji Mohamed Salleh's narration, when Francis Light came ashore, he saw around 30 Malays on the beach, led by someone called "Nacodah Kichil". This group of Malays was permitted to clear the forest to build a settlement for themselves. Haji Mohamed Salleh later came to work for "Nacodah Kichil" and established a settlement in an area called "Jullutong", thus founding a Malay settlement in the area that is still known today as Jelutong.

Not long after this, many more people came to settle in Tanjong Penagar, clearing the forest, building houses and bringing their families and followers with them. Apart from the Malays who mostly came from Kedah, Pattani and Sumatra, some Englishmen and Siamese also came to settle in the new areas of land. The entire account by Haji Mohamed Salleh can be summarized as follows:

The Malays who came to the island with Francis Light cleared the land and established a settlement in Datu Cramat (Dato' Keramat, 1786). 
Seven years later, Danbie Chand cleared the land and established a settlement in Batu Lanchang (1793).

Two years later, Captain Scott and Mohamad Prie from Songkhla cleared the land and established a settlement in Glughore (Glugor, 1795).

Nacodah Intan cleared the land and established a settlement in Batu Uban (1795).

One year later, a European named Raboo and Hakim Tuduh cleared the land and established a settlement in Sunghie Nibong (Sungai Nibong, 1796).

A Malay called Loh Manu cleared the land and established a settlement in Sunghei Kluang (Sungai Kluang, 1796).

After spending 12 years in Penang, Haji Mohamed Salleh moved and settled in Bayan Lepas (1798) together with Long Syed.

Pah Kichil from Batu Bara and Jamuludin and Nacodah Che Salleh from Lingga cleared the land and established a settlement in Permattang Dammar Laut (Permatang Damar Laut).

Tunku Utas and Toh Ninah (a Siamese) cleared the land and established a settlement in Batu Mow (Batu Maung).

Nacodah Seedin from Delhi and Punglima Long from Sittool (Setul) settled in Tellok Coomber (Teluk Kumbar).

Tukong Po from Purlis (Perlis) and Lebbi Tampak from Delhi cleared the land and established a settlement in Bali Pulo (Balik Pulau).

An Englishman named Bacon cleared the land and established a settlement in Ayer Itam (Air Itam).

This oral account that Vaughan received from the descendant of Haji Mohamed Salleh is only a brief record but includes several important areas in Penang, especially those in the northeast and southwest of the island. The dates of when some of these areas were settled is sometimes clear, while for some other areas, only a rough estimate can be made. Areas in the northeast 
that are mentioned include Penaga, Dato' Keramat, Batu Uban, Jelutong and Glugor.

Vaughan certainly was not aware of the value of the narration he recorded in 1857, for it is included at the end of his writings almost as an afterthought. The name of the descendant of Haji Mohamed Salleh who related the narration is also not recorded. There is also no further elaboration concerning the people named in conjunction with the settlement of the areas. As far as is known, Haji Mohamed Salleh's narrative was only published once by Vaughan, in 1857. The fact remains that to this day, this narrative is an important heirloom when it comes to the early history of Penang. It was recorded around 71 years after the settling of Penang by Francis Light, a relatively short length of time as it spans only one or two generations of Malay settlers in Penang.

Haji Mohamed Salleh's narrative is also valuable as an example of oral history (local history) about Penang's early history. While Vaughan did not follow the correct methods of study of oral history, it is unquestionably authentic. Furthermore, the material was published by a British officer in an influential journal at the time, The Journal of the Indian Archipelago and Eastern Asia (1857). Apart from Haji Mohamed Salleh's narrative, Vaughan's writings also contain another account concerning the early history of Penang that is of no less importance: "Legenda Nakhoda Ragam" [The Legend of Nakhoda Ragam].

Vaughan writes that Nakhoda Ragam was a trader who often sailed between Lingga and Kedah. Between these two places, only one island stood out for him to stop at. He named this island "Pulo Ka Satu", which can be rendered in modern Malay as "Pulau ke Satu", meaning "single island". It is possible that after this time, the name "Pulo Ka Satu" was used, especially by traders plying the waters of the island, and could have also been adopted by the people living in the surrounding areas: "The ancient name of Pulo Pinang was Pulo Ka Satu and thus do they account for its derivation" (Vaughan, 1857, p. 168).

Apart from the naming of "Pulo Ka Satu", Nakhoda Ragam is also said to have named several other places on or near the island (Vaughan, 1857, pp. 168-169), among them being "Pulo Kindi", "Bayan Lepas", "Gerattah Sangkol", "Pulo Bittong" and "Puchut Muka". All these places still exist today, several of them on the southwest of the island: Pulau Kindi, Bayan Lepas, Geretak Sanggul, Pulau Betong and Pucat Muka (Muka Head). These place names are some of the original settlements in Penang that are 


\title{
CERITA NAKHODA RAGAM DENGAN TUAN PUTERI LAILA MENCANAI
}

\begin{abstract}
Di negeri Brunei Darussalam kononnya Sultan Brunei yang kelima dikenali dengan panggilan Nakhoda Ragam atau dipanggil juga Anak Kuda Ragam. Baginda adalah salah seorang sultan yang gah namanya dan dihormati oleh seluruh rakyat dan pembesar. Baginda juga suka mengembara ke serata daerah di Alam Melayu. Di samping itu baginda berperawakan riang, tenang dan selalu gembira. Baginda amat suka menyanyi dan bersiul serta bersenang-senang hati seorang diri. Maka itulah sebabnya baginda digelar Nakhoda Ragam, iaitu seorang nakhoda yang suka bergembira berbagai ragam.
\end{abstract}

\section{Baginda Nakhoda Ragam memerintah Brunei}

Figure 3 A page from Cerita Tradisi Brunei.

(Source: Taha Abd. Kadir, 1985)

attributed to Nakhoda Ragam. Based on that, it appears that Nakhoda Ragam had explored a large area of Penang, reaching even Pulau Betong, which is located near Balik Pulau.

To date, the true identity of Nakhoda Ragam remains a mystery, as there is no concrete evidence of his existence. His heroic exploits not only feature in the oral tales of Penangfolk, but he is also linked to legendary figures in Johor and Melaka. Legends about Nakhoda Ragam have long existed in the oral tradition of the Malays in Brunei Darussalam. One of the legends involving Nakhoda Ragam and Tuan Puteri Laila Mencanai is recorded in the collection titled Cerita Tradisi Brunei, compiled by Taha Abd. Kadir (1985). ${ }^{3}$

In Johor, there are legends about Nakhoda Ragam in which he is said to be linked with Puteri Gunung Ledang, the legendary princess of Mount Ophir. In this version from Johor, Nakhoda Ragam is the husband of Puteri Gunung Ledang. However, he dies after being stuck by the needle used by the princess to sew her clothes. This oral tale was once told to Braddell (1853, p. 102) and is recorded in his "Notes of a Trip to the Interior from Malacca". The tale of the death of Nakhoda Ragam goes as follows: 
The above named Nakodah Raggam was the husband of the more celebrated Putri Gunong, (or as it was at that time Pulo Ledang. Pulo means island, the tradition being that Mount Ophir was formerly surrounded by the sea). One day the Putri was sewing, and her husband, who was sitting with her in the vessel's cabin, commenced to tease her, she told him to let her alone, but persisting, his finger was pricked by her needle. Unfortunately he died from the wound.

Another story concerning Nakhoda Ragam can be found in Hikayat Anggun Cik Tunggal, a work of the Malay penglipur lara (storytellers) that was published by Winstedt in 1960. This hikayat (Malay prose) was originally narrated by Pawang Ana, a penglipur lara who lived in Gopeng, Perak. Among the other hikayat in Pawang Ana's repository were Hikayat Awang Sulung Merah Muda, Hikayat Bayan Budiman and Hikayat Raja Muda. In 2001, Hikayat Anggun Cik Tunggal was republished in a series of great works issued by Yayasan Karyawan in Kuala Lumpur. The name "Nakhoda Ragam" only appears in one episode involving a sea battle between Anggun Cik Tunggal and Nakhoda Ragam. The presence of Nakhoda Ragam's ship is recorded as follows (Cerita Lipur Lara Tuturan Mir Hassan dan Pawang Ana, 2007, p. 313): "Sebuah lancang kuning terlalu amat elok, nama nakhodanya Nakhoda Ragam." ["There was a beautiful yellow lancang (merchant ship) captained by Nakhoda Ragam."]

It is difficult to determine whether the character Nakhoda Ragam in Hikayat Anggun Cik Tunggal is the same as the Nakhoda Ragam who is credited with having named Pulo Ka Satu. The researcher can only assume that Pawang Ana, who originated from Rawa (Rao) in Sumatra, had once heard a tale about Nakhoda Ragam and included the character in one of his hikayat. However, in Hikayat Anggun Cik Tunggal, Nakhoda Ragam is actually a princess who wishes to test Anggun Cik Tunggal's prowess at battling at sea. In the end, Anggun Cik Tunggal concedes defeat to the great Nakhoda Ragam. This also suggests that Nakhoda Ragam was already known as a heroic character among the Malays in the Malay World, which led to the creation of an oral tale about a princess in disguise being this great character.

Apart from this, the legend of Nakhoda Ragam found in Melaka is more interesting, as it is linked to the charismatic Sultan Bolkiah from the Sultanate of Brunei. This is mentioned by Low (1998) in "Selesilah of the Rajas of Brunei". Sultan Bolkiah was the fifth ruler of the Sultanate of Brunei, reigning between 1485 and 1524 . He was known for his voyages 

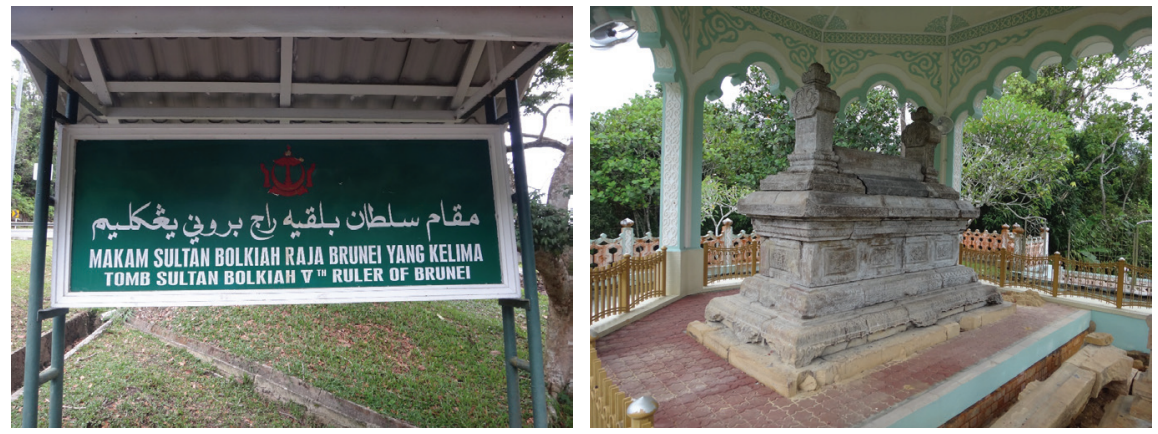

Figure 4 Two photos of the mausoleum of Sultan Bolkiah (Nakhoda Ragam) at the Royal Brunei Mausoleum in Jalan Tutong, Bandar Seri Begawan, Brunei Darussalam.

and explorations of the Malay World, reaching Java, Melaka and several islands around Borneo. Low (1998, p. 5) records the following:

Sultan Bulkeiah was familiarly known as Nakhoda Ragam. He is described in Bornean traditions as a great navigator and warrior, having voyaged to Java and to Malacca and conquered the East Coast of Borneo, Luzon and Soolook.

Low also notes other details about Nakhoda Ragam in the Malay World. The name "Ragam" itself is linked to the various activities that he undertook in his travels in the Malay World, through which he reached Johor. The presence of Nakhoda Ragam in Johor could indirectly explain why there is a tale linking this character with Puteri Gunung Ledang. Low notes the following (1998, p. 16):

Sultan Bulkeiah, called Nakhoda Ragam, on account of his numerous caprices. He seems to have been a person of great activity and intelligence, made many voyages to Java, Malacca, Johor, and other places, and conquered the countries of Soolook and Luzon.

Sweeney (1998, p. 99), in a transliteration of Silsilah Raja-Raja Berunai that is based on MS 123 kept at the Royal Asiatic Society in London, also records the following information about Sultan Bolkiah: "Sultan Bulkia ialah juga dinamakan orang tua-tua Nakhoda Ragam." ["Sultan Bulkia was 
JELANI HARUN

\section{APPENDIX "A" \\ A Chronological list of the Sultans of Brunei.}

1. Sultan Mohamed.

2. Sultan Ahmed.

3. Sultan Berkat.

4. Sultan Suleiman.

5. Sultan Bolkiah (Nakhoda Ragam).

6. Sultan Abdul Kahar (Merhum Keramat).

7. Sultan Saif ul Rejal (Merhum di-Budu).

8. Sultan Shah Brunei.

9. Sultan Hassan (Merhum di-Tanjong).

10. Sultan Jalil al Akbar (Merhum Tuah).

11. Sultan Jalil al Jabar (Merhum Tengah).

12. Sultan Mohamed Ali (Merhum Tumbang di-Rumput).

13. Sultan Abdul Mobin (Merhum di-Pulau).

14. Sultan Muhidin (Merhum Bongsu).

15. Sultan Nasrudin (Merhum di-Changi) $\dagger$

16. Sultan Kamaludin (Merhum di-Lobah) $\dagger$

17. Sultan Mohamed Ala'udin (Merhum di-Brunei) $\dagger$

18. Sultan Omar Ali Saifudin (Merhum di-Makam Besar).

19. Sultan Mohamed Tajudin.

20. Sultan Mohamed Jemal ul Alam.

21. Sultan Mohamed Kanzul Alam.

22. Sultan Mohamed Alam.

23. Sultan Omar Ali Saifudin II.

24. Sultan Abdul Momin.

25. Sultan Hashim Jalil ul Alam Akamudin.

26. Sultan Mohamed Jemal ul Alam (II) K.C.M.G.

27. Sultan Ahmed Tajudin Akhazul Khairi Wadin.

Figure 5 List of ancestors and descendants of Sultan Bolkiah (Nakhoda Ragam). (Source: Hughes-Hallett, 1998)

also known among the older folk as 'Nakhoda Ragam'."] This shows that Sultan Bolkiah was noted in the genealogy of the sultans of Brunei to have been known by the moniker Nakhoda Ragam. Hughes-Hallett (1998, p. 31), in his elaboration on the history of Brunei Darussalam, depicts the great Sultan Bolkiah as follows:

Sultan Bolkiah was a renowned sea rover who voyaged to Java and Malacca and made conquest in Borneo, the Philippines and Sulu and even seized Manilla. The names of many islands scattered throughout 
the archipelago are alleged to commemorate the circumstances of his voyages. One legend is that he set out on a cruise with a gantang of pepper seeds and was not content to return until he had given to each seed the name of one of the myriad islands encountered.

Hughes-Hallett's depiction above provides a clearer picture of Sultan Bolkiah and the possibility that it was indeed this sultan who was the Nakhoda Ragam who reached Penang in the later $15^{\text {th }}$ and early $16^{\text {th }}$ centuries. The fact that he was able to sail to Java and Melaka makes it possible that he would have also sailed the waters of Lingga and Kedah and traded at other Malay ports. Based on the tales of the seafaring Sultan Bolkiah from Brunei, there is the possibility that, as Nakhoda Ragam, he could have come to Penang in the later $15^{\text {th }}$ and early $16^{\text {th }}$ centuries and named the as-yet unnamed island "Pulo Ka Satu". The excerpt above by Hughes-Hallett suggests that Sultan Bolkiah often named places or islands at which he stopped.

It is not known when the name Pulo Ka Satu came to fall out of use among the people of Penang. According to Vaughan (1857, p. 168), not long after the time of Nakhoda Ragam, the people of Province Wellesley (presentday Seberang Perai) called Pulo Ka Satu "Tanjong Penagar" because of the penaga (Alexandrian laurel) trees that grew in the area where Fort Cornwallis was later erected. The name "Tanjong Penagar" or "Tanjung Penaga" was later adopted by the local people for Pulo Ka Satu.

\section{"The Legend of Nakhoda Ragam" vs. the Historical Account of Francis Light}

The name "Pulau Pinang" only emerged after "[t]he Areca, or Betel Nut" was planted on the island. It is not entirely certain when this palm was first cultivated in Penang (Beighton, 1988). "Pulau Pinang" first received some attention when the British East India Company signed several treaties with the Sultan of Kedah beginning in 1771, involving areas that included Penang. The Sultan of Kedah at the time was in dire need of military aid from the British East India Company, as he faced threats from Burma and Siam. The climax was a treaty signed on 11 August 1786, when Francis Light successfully obtained the consent of Sultan Abdullah Mukarram Shah (1778-1798) to settle in Penang.

After landing on the island, Francis Light retained the name "Poolo Peenang", while at the same time giving it a new name, Prince of Wales Island. However, the researcher is certain that Francis Light was familiar 
with its previous names, such as Pulo Ka Satu and Tanjong Penagar. The evidence for this can be found in an article by Garnier titled "Early Days in Penang", which was published in JMBRAS (1) in 1923. On page 5, the sentence begins as follows:

On the morning of July 15th 1786 Pulo Pinang - Pulo Ka Satu - lay sleeping in the sun, as quiet and untrodden by human feet as any other of the many jungle-covered islands in these Eastern seas.

From the excerpt, it is evident that as of 15 July 1786, the name "Pulo Ka Satu" was still in existence and was known to the British officers who were there at the time. While Francis Light maintained the name "Poolo Peenang", he had also renamed it as Prince of Wales Island to commemorate the birth of the Prince of Wales (George Augustus Frederick, the British crown prince born on 12 August 1762), who would later ascend the throne as King George IV (1820-1830). The two names of the island are not related in any way and there is no other historical significance that can be found. As a result of this lack of correlation in meaning and historical significance, the name "Prince of Wales Island" passed out of use among the inhabitants of the island, while the name "Pulau Pinang" persisted.

Garnier (1923, p. 5) also records the presence of about 50 kampong (village) folk at Pulo Tikus who came to witness the arrival of the British ships, which were very alien to them at the time. According to Skinner (1895, p. 3), as many as 52 Malays came from areas near Tanjung Tokong to help clear the jungle. ${ }^{5} 50$ people is not a small number and, in fact, may only have been a portion of the much larger number of inhabitants. Do these notes by Garnier and Skinner reveal that there was already an existing Malay settlement in Pulau Tikus and Tanjung Tokong? In fact, both Garnier and Skinner record the events of the landing of Lieutenant Gray's ship at "Point Penagger" on 17 July 1876, in preparation for the arrival of Francis Light the next day, which sheds more light on the fact that Tanjong Penagar (Tanjung Penaga) was already in existence at the time. On the presence of the 50 kampong folk, Garnier (1923, p. 5) writes:

At midday three ships dropped anchor off Pulo Tikus, boats were lowered and soundings taken. The same thing happened the following day, and no doubt the fifty odd original inhabitants came from their kampong under the hill, by narrow jungle path down to the sea shore to find out what these strange ships were doing. 
After Francis Light landed in Penang, work to clear the thick jungle that still covered the island commenced; apart from some "inhabitants of the island", workers - including Indians and Chinese-were brought in from Kedah. "Extracts from [the] Journal of Captain Francis Light", which is found in "Notices of Pinang" (Logan, 1850, pp. 629-630), contain notes on the early days of Francis Light's settling in Penang. Light's notes state, among others:

18th July 1786

Landed the European - the marines and lascars employed clearing the wood and pitching their tents. The Dato of Qualla Moodoo came. He brought a fishing net and desired permission to erect a house, which I readily granted, a prahu from Queda likewise arrived with Captain China and some Christian of India, they also brought a net which was very acceptable. (p. 629)

\section{9th July 1786}

People employed clearing the woods: Some of the inhabitants of the island, who dwelt at the foot of the hill, paid me a visit and offered their service to assist me, I dismissed them with a present. (pp. 629-630)

\section{3rd July 1786}

Pleasant day, the people from Queda erected a small Bazar near the cantonments, appointed Noqueda Catchee to super-intend the Bazar and prevent impositions on either side, ordered him a guard of marines. (p. 630)

Francis Light's notes above show that there were a few original inhabitants who lived at the foothills of Penang at the time. It is difficult to ascertain their identities but it can be assumed that they were Malays who had long settled and lived in the area, and who had the courtesy and courage see Francis Light and offer their services to clear the jungle. Notes by Dalrymple (1886, p. 28), which was published by Maxwell in Volume 1 of Miscellaneous Papers Relating to Indo-China, may also shed light on this. In "Formation of the Establishment on Poolo Peenang" (pp. 26-37), Dalrymple narrates:

A French padre and 100 Christians, small and great, are come from Quedda to settle, besides a number of stragglers. The formal inhabitants amounted to 58 men, women, and children, who reside near the foot of 
the hills about four miles from us, several Chinese are likewise come to ask for ground to build on, and mean to bring their families here.

Dalrymple's notes give an indication of the Malay community that lived at the foothills of Penang and who numbered about 58 people, which was sufficient enough to be considered a sizeable community settled in an area. They may have been fishermen or farmers but they lived at the foothills and had families and a leader; they did not merely anchor briefly at the island's shores or establish temporary settlements while waiting for the monsoon to turn to sail off.

Of no less importance is Dalrymple's note about a French priest in Penang at the time, who would have certainly played an important part in spreading Christianity in Penang in the early days. The identity of this priest is not revealed in detail. However, his description, which is as follows, seems to coincide with that of Garnier (1923, p. 5):

Perhaps, in the same boat came the French Padre, who, Light tells us, landed among the first arrivals and planted his Cross on the soil of Penang.

The answer to the mystery of the Padre in Penang may lie in an article by Reid (2009, p. 178), which records about the coming of several Roman Catholic priests from Siam to Kedah in the 1780s. When Francis Light sailed from Kedah to establish a new settlement in Penang in 1786, many Roman Catholics came with him, including a priest by the name of Garnault. While it cannot be said for certain that the priest mentioned by Francis Light and Garnier is Garnault, it does not seem baseless to believe so. Moreover, according to Reid (2009, p. 183), in 1808, a College Generalle (College General) was established in Penang as a place for teaching the Roman Catholic faith. One of the main figures was a priest by the name of Mathurin-Pierre Pecot, who published three books in Malay in 1826, 1827 and 1829 respectively. These three books were published in Paris and became the main texts in Malay for the teaching of the Roman Catholic faith in Penang.

The narrations about the early Malay community in Penang require further research. Many more narrations and historical writings must be unearthed and highlighted as historical sources that may invite new interpretations. 1786 is not so distant in the past, as writing and publishing activities were actively carried out in Europe at the time. According to Col. Nahuijs (see Miller, 1941, p. 208), during the process of clearing the jungle in Penang 
by the English officers, many ancient graves were uncovered, which are evidence of Malay settlements having existed in the area:

At the time it was first taken over by the English the island was well wooded and almost uninhabited except by a few humble fishermen who dwelt only on the coast. In 1801-1802 the whole population totalled barely 10,000 souls. An old tradition of the natives described Poeloe Penang as a countryside that in previous centuries was heavily populated and the numerous burial places which the Englishmen found here on their first settlement, lend much colour to the tale of the natives.

\section{CONCLUSION}

"Legenda Nakhoda Ragam" [The Legend of Nakhoda Ragam] is the tale of a charismatic trader or maritime adventurer in the Malay World, and whose history is difficult to prove conclusively. Nakhoda Ragam is linked with several places and the naming of these places in Penang, Johor, Melaka and Brunei, which indicates the fame this character enjoyed in the Malay World. Unfortunately, historical facts concerning Nakhoda Ragam have not yet been found; he remains a mystery due to the lack of written documentation about him. However, the absence of concrete proof does not mean there is no truth in his existence. Narrations and notes made by Europeans from the time of Francis Light's settling in Penang in 1786 and well into the $19^{\text {th }}$ century do indicate the existence of Nakhoda Ragam among the Malays in the past. Furthermore, the fact that the capricious Sultan Bolkiah of Brunei in the late $15^{\text {th }}$ and early $16^{\text {th }}$ centuries was known as Nakhoda Ragam opens up the possibility that he could be the Nakhoda Ragam credited with naming Penang "Pulo Ka Satu". Legends continue to play a role in strengthening and preserving historical documentation, especially where the founding of settlements that took place hundreds of years ago is concerned.

\section{NOTES}

1 Based on "Wu Pei Chi Charts of the 15th century" (Douglas, 1980, p. 477). Kong Yuanzhi (2000), in his study of the voyage of Admiral Cheng Ho from China to Melaka in the 15th century, has found several sketches of maps done by Admiral Cheng Ho of the areas of Melaka (Ma La Jia), Langkawi (Long Ya Jiao Yi), Kuala Kedah (Ji Da Gang) and Penang (Bin Lang Yu). 
2 Langenes and Jodocus Hondius, two Dutch travellers, travelled in the Malay World at the end of the 16 th and the early 17 th centuries.

3 Refer to several examples of folktales from Brunei Darussalam in Harun Mat Piah (2003).

4 The capital of the state, George Town, takes its name from the father of the Prince of Wales, King George III (George William Frederick, 1738-1820), who reigned England from 1760 to 1820 .

5 This suggests that one of the earliest Malay settlements could have been at Tanjung Tokong. Skinner (1895, p. 3) writes:

The place was practically unoccupied. The only Malay inhabitants heard of were 52 Malays who came over, apparently from near Tanjong Tokong, to help in felling the forest.

\section{REFERENCES}

Beighton, J.T. (1888). Betel-Nut Island. London: The Religious Tract Society. Braddell, R. (1853). Notes of a Trip to the Interior from Malacca. JIAEA, VII, 73-104. Cerita Lipur Lara Tuturan Mir Hassan dan Pawang Ana (researched and introduced by Mohd. Taib Osman). (2007). Kuala Lumpur: Yayasan Karyawan.

Dalrymple, A. (1886). Formation of the Establishment on Poolo Peenang. In W.E. Maxwell (ed.), Miscellaneous Papers Relating to Indo-China. Vol. 1. London: Trubner \& Co. and Ludgate Hill.

Douglas, F.W. (1980). Notes on the Historical Geography of Malaya and Sidelights on the Malay Annals. MBRAS (Reprint no. 7).

Garnier, K. (1923). Early Days in Penang. JMBRAS (1), 5-12.

Harun Mat Piah. (2003). Sastera Rakyat Malaysia, Indonesia, Negara Brunei Darussalam: Suatu Perbandingan. Kuala Lumpur: Dewan Bahasa dan Pustaka. Hoyt, S. H. (2001). Old Penang. Shah Alam: Oxford University Press.

Hughes-Hallett, H. R. (1998). A Sketch of the History of Brunei. Papers Relating to Brunei. MBRAS Reprint Number 18, pp. 28-45.

Jelani Harun. (2014). Pulo Ka Satu: Warisan Sejarah Awal Persuratan Melayu Pulau Pinang. Kuala Lumpur: Perpustakaan Negara Malaysia.

Jelani Harun. (2014). Legenda Nakhoda Ragam dalam Sejarah Awal Pulau Pinang. In Ampuan Haji Brahim bin Ampuan Haji Tengah (ed.), Cetusan Minda Sarjana. Bandar Seri Begawan: Dewan Bahasa dan Pustaka, pp. 233-251.

Kong Yuanzhi, (2000). Pelayaran Zheng He dan Alam Melayu. Bangi: Penerbit UKM. Logan, J.R. (ed.). (1850). Notices of Pinang. JIAEA, IV. Singapore: G.M. Frederick, Low, H. (1998). Selesilah of the Rajas of Brunei. Papers Relating to Brunei. MBRAS Reprint Number 18, 1-24.

Markham, C. R. (ed.). (1877). The Voyages of Sir James Lancaster to the East Indies. London: The Hakluyt Society. 
Maxwell, W.E. (1885). Notes and Queries. JSBRAS.

Miller, H. E. (1941). Extracts From the Letters of Col. Nahuijs. JMBRAS, 19, 146-209.

Moreland, W.H. (Ed.). (1934). Peter Floris: His Voyage to the East Indies in the Globe 1611-1615. London: The Hakluyt Society.

Navarette, R.F.F. D. F. (1934). An Account of the Empire of China. JMBRAS, 12, 89-93.

Reid, A. (2009). Fr Pecot and the Earliest Catholic Imprints in Malay. In Jan van der Putten \& Mary Kilcline Cody (eds.), Lost Times and Untold Tales from the Malay World. Singapore: NUS Press, pp. 177-185.

Report of the Colloquium on Oral History. (1978). Petaling Jaya: National Archives of Malaysia.

Skinner, A.M. (1895). Memoir of Captain Francis Light. JSBRAS, 28, 1-17.

Suarez, T. (1999). Early Mapping of Southeast Asia. Singapore: Periplus.

Sweeney, P. L. A. (1998). Silsilah Raja-Raja Berunai. Papers Relating to Brunei. MBRAS Reprint Number 18, 46-127.

Taha Abd. Kadir. (1985). Cerita Tradisi Brunei. Petaling Jaya: Pelanduk Publications. Vaughan, J.D. (1857). Notes on the Malays of Pinang and Province Wellesley. JIAEA 11(2), 115-175. Singapore: Jacob Baptist.

Received: 23 June 2020

Accepted: 18 August 2020 